\title{
MORT'S LAWS
}

\section{Ten commandments for a New Dawn.}

\section{BY JACEY BEDFORD}

C $\bigcirc$ hut up! All of you!" Morton's bellow silenced the squabbling voices in the cellar of the burned-out building. "You asked me here - now talk. One at a time."

He perched on the edge of the squared-off pile of rubble that passed for a table. Kids, he thought. I used to see 'em as troops, but they're no more than kids. When I was their age ...

He stopped himself from heading down the nostalgia route. He'd never been their age. He'd grown up in the days of cars and air conditioning, Wal-Mart and cheap Chinese footwear. He'd lived in a house with a roof on it and had a real high school to drop out of. He'd even had a father, though the surly sot hadn't taught him more than how to dial for pizza delivery.

His father had probably been killed in the first wave of the invasion, but Mort would never know. He'd been in the Marines by that time. Found himself a family he could rely on. He'd stayed loyal to that family until he was the last man standing, then hed gathered a new family, teaching the survivors what he knew about fighting aliens.

The slow and the old had died a long time ago, except for Mort. He was a living tribute to his drill sergeant's training, and a walking advert for good luck.

Andi Ferriby stood up to speak. At 28 she was her squad's matriarch, savvy, sassy and as tough as they came. Mort had trained her to field-strip and reassemble the clumsy MM49s back in the days when they'd still had ammo. Even then the damn things were better used as a club. You could pump five rounds into a grom and they wouldn't falter, but they were fragile in the brain-pan. Left temple was the place to whack for best effect.

But that was over now. The fighting had finished.

Had they won? Mort hadn't a clue, but they'd survived in scattered groups. Was it enough? It had to be. They could rebuild communities, relearn skills.

It had started suddenly, with an armada of alien vessels raining down destruction on missile silos, oil supplies and communications towers simultaneously. The groms themselves, named after the only recogniza-

$\rightarrow$ NATURE.COM Follow Futures: @ @NatureFutures $f$ go.nature.com/mtoodm ble sound they made, didn't seem to have any weapons other than blades, but kill one and two would

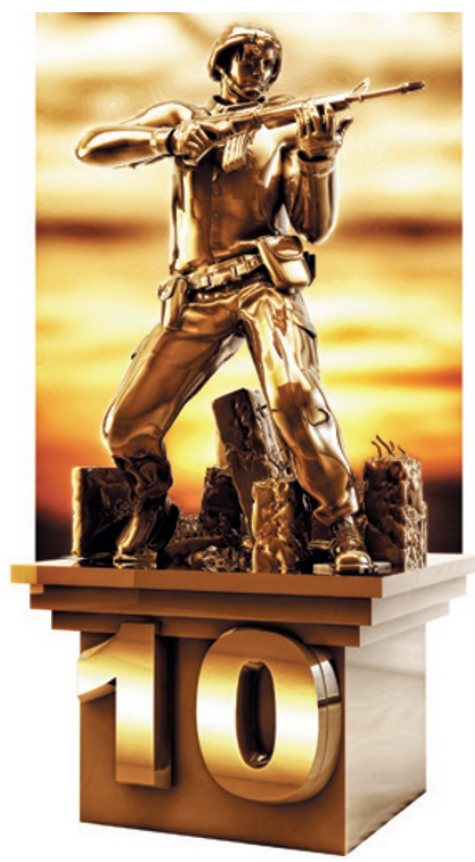

take its place. A seemingly endless supply of alien cannon-fodder, millions of them. Billions. And in the end, sheer numbers won out over artillery and projectile weapons.

Inexplicably the squat, muscular aliens had stopped short of genocide, having knocked the planet back into the dark ages, country by country, town by town. Perhaps it was sport to them. Perhaps teaching upstart humans their place in the Universe had been their objective all along. Who could tell? They'd never been able to communicate.

Mort figured it had taken 40 years of offensive and counter-offensive to reduce eight billion people to a few ragged survivors. None of these kids remembered what it was like before.

Thirteen of them now stared at him expectantly. “OK. You talk first.” He pointed to Andi.

She nodded. “Gran'f'er Mort, we know about fighting and hiding, but we don't know how to live peaceful. Just yesterday, Ainley's bunch came at us for supplies, but we don't hardly have any more than they do. They had nothing to trade. We had to send 'em off, but there was hurting on both sides. Now the groms have gone, we shouldn't be fighting each other."

Mort shook his head. How could they rebuild what they'd never known?

"Time was, there was rules about that. My ma said so." Jimmy York held out something small in his strong, brown hand.
Mort took it and felt his fingers tremble as he recognized a tightly folded page from a book. Reverently he opened it out.

"Where'd you get this?"

"Ma," Jimmy said. "She said if we was gonna ever be civilized again we'd need to be able to read an' write. She tried to teach me, but ... no time." He shrugged. "She's gone now. Ain't no one can read in our squad."

There was nothing left to read. Books all gone three decades ago; pages ripped out for arsepaper or burnt for winter warmth.

Mort squinted at the rubbed print on the worn paper, only gradually making out the words...

Hills of the North, Rejoice.

Immortal, Invisible, God Only Wise.

Hell! An index page from a hymn book!

The long-dead military chaplain's voice echoed in his head, but only the sermon's tune remained - the words had evaporated.

No matter, he'd never believed anyway.

But these kids needed some basic rules to build on. If only he could remember the Ten Commandments. He dredged dim memory, found gaping holes, and invented what he'd forgotten.

That's how the New Dawn got Mort's Laws:

1. Worship no gods.

2. Don't kill what you can't eat.

3. Treat others kindly, as you would be tret.

4. Honour your family and your squad.

5. No thieving, ask nicely or offer trade.

6. No lusting after your neighbour's ass.

7. Learn all you can learn, and teach others for free.

8. Tell the truth and shame the devil.

9. Always wash your hands after using the latrine.

10. Never start a fight, but always finish it.

In later years the lawmakers built a statue of Mort in the square of Newtown City. Every Saturday morning the philosophers would gather to teach anyone who would learn, talk to anyone who would listen, and debate with anyone who would speak. Always, the most hotly argued point was number six. -

Jacey Bedford has had short stories published on both sides of the Atlantic and her first novel Empire of Dust is out now with the sequel due in August 2015. 